\title{
The Socio-Cultural Context in Syria Gender-Role Stereotypes and Attitudes towards Female Academics Career Advancement
}

\author{
Lina Ourfali, Alaa Mardam Bek, Serene Dalati* \\ Management Department, Faculty of Business Administration, Arab International \\ University, Syrian Arab Republic \\ Corresponding author: s-dalati@aiu.edu.sy
}

\begin{abstract}
The purpose of this research is to investigate gender role stereotypes and attitudes towards female academic is career advancement in Syria. The research methodology analyzes 100 male and female respondents by distributing questionnaire on Arab international University academics. There are differences between men and women attitudes towards woman career advancement. Research results are generally in favor of women academics work and management. Although there is significant difference between men and women responses. Research limitations are associated with sample size and limited scope. The study focused only on one institution. The Research examines four variables attitudes towards gender roles and women's career advancement. The results indicate that in general academics have positive to moderate attitudes towards women academics careers advancement and managerial status. There is a significant difference between male and female academics attitudes.
\end{abstract}

Keywords: Attitudes, gender role stereotypes, women managers, female academics. 


\section{Introduction}

In many countries' women are considered less adequate to occupy a managerial and decision-making positions. The collections of research that deal with topics, which examines issues about women in management are the most remarkable examples in Asia, Europe, and the Middle East (Adler \& Izraeli, 1994, Al Salem and Speece 2017). This research reports the results of study that indicates one important question related to women representation at senior organizational levels in the Middle Eastern region.

Research studies imply that women are subject to the control of patriarchal societies due to the interconnectedness of their community structure. The effects of this problem have given rise to a generation of women in academic and professional sectors considered as lacking confidence and inadequate experience at top management levels and upper-income levels (Dalati 2021).

The purpose of this research to examine the social situation with a focus on attitudes towards women's career advancement. The unbridled development of women's empowerment at work at global and Arab societies in general and in Syria in particular, the professional environment for academic women that can go beyond certain factors and must be developed in order to succeed in today's new model of empowering women at the societal and cultural level. The desire to empower academies is rising, as international and global societies depend on the important roles that academies do (Aycan, 2004).

Previous studies signify that there is a shortage of women academics in key areas of increasing importance in academic institutions in the Middle East and Southern Mediterranean region. There is a need to develop effective academics with technical, interpersonal, conceptual and decision-making skills that can maintain a strong and sustainable academic environment. Challenges related to social, cultural and professional issues are clear factors that can hinder the role of academies in assuming leadership and leadership roles in the academic environment (Dalati and Hamwi 2016). On the one hand, the flow of information, technological advances and interdependence, the struggle for analytical and research competencies, and the increase in ethical problems were among the important factors that stimulate the need for women leaders who have acquired effective competencies that can go beyond cultural, geographic, political, ethnic and national aspects. It is clear that persistent social norms inhibit female professionals from assuming leading organizational roles in education in the Arabic region and Southern Mediterranean parts.

Gender inequality is a phenomenon with undesirable effect on social, economic and political aspects of society. Attaining economic freedom has good consequences on the economy, and will lead to better use of human capital in any given country. There is a gender gap in various sectors where women are found to be overrepresented in the low-wage sectors and underrepresented in higher management levels and decision-making positions.

\section{Literature review}

There are social activities in the sense of Middle Eastern culture that institutionalize negative discrimination against women, frequently codified in legislation forbidding women participating in a substantial part of different aspect of life or opposing 
entirely in the labor market. The number of women in this region is low and fertility rates are high due to the early age at first marriage, the high rate of maternal and child mortality, the high rates of illiteracy among women, their lack of access to university level, and the difficulty of women's participation in the labor market due to government laws and the culture of society that does not support women (Dalati, 2020).

In the same field in Saudi Arabia, women's experiences of becoming leaders and the influences of leadership practice were examined and analyzed to predict the obstacles that may face them according to the assumptions of history, language, religion and society and this is because of their special country case (Hodges, 2017).

The impact of social-cultural factors affecting female representation at top managerial roles was investigated by Aycan (2004), who researched the causes of women's underrepresentation at senior organizational levels in Turkey and shown the effect of social-cultural factors, defining gender-role stereotypes and understanding of women's career advancement.

A study on Oman was about determining the importance of emerging process of women's empowerment, and as women leaders in patriarchal, male-dominated work settings, it seeks to capture their characteristics, perspectives and challenges (Asya Al-Lamky, 2007).

Even though Kuwaiti women are the most fortunate in the Arabic region, they are ranked third after Qatar and the Emirates, but they still suffer from the problem of inequality between men and women in job opportunities, wages and conditions, her lack of promotion, her access to administrative positions and her permission to make decisions. The economic participation of Arab women remains the lowest in the world (Al-Salem, 2017). Shahine (1997) in a study on the Middle East found that women suffer from educational, social and socialization pressures, which prohibit women to form its own values and perceptions in leadership roles. Almenkash (2007) mentioned that women possess a high level of responsibility in job role, which it's not appropriate with their capabilities.

According to the study of UK that covers the double burden on women. Which focusses on the life and choices of profession women have made, taking into consideration cultural burdens and practical consideration. There are a number of factors related to dual problem; one is the regular work of home responsibilities which is a primary profession in women's life, two is the extra demands on time one and the emotional strain that accompanies caring responsibilities. In addition, the problem of most people is working in the library management profession are women, yet men are the ones with highest wages (Elizabeth McDermott, 1998).

There's another study was conducted in Montreal, Canada states that despite an increase in percentage on female professionals who attained managerial positions is still low compared to men. This case focuses on the problem of developed and developing countries. These western and eastern cultures are the result of educational 
barriers and legal restrictions placed on women. Even though Canada considered as a developed country but women still represent minimal representation senior management level (Adler, 1993).

In Australia, a study was also conducted to examine the situational, personal and environmental factors that affect the administrative progress of women, and the influence of person and position variables on the progress of men and women, analyzing gender-related differences to take into account their effect on the progress of personal variables and specific attitudes((Tharenou and Conroy, 1994).

Forces at work impelling female professional progression. Prior studies indicate individual factors affecting women's attitudes for higher levels and professional progression, related demographics affecting work and early socialization.

It is noted that women's who has evolved in their work contains a specific attribute which are self-efficiency, constant pursuit and desire to be successful, positive attitudes towards acclimatization factor and the reliability in inner sense of success (Greenhaus \& Parasuraman, 1993; Lobel \& St Clair, 1992; Ragins \& Sundstrom, 1989). According to the previous studies, research found that women who have both higher education and socioeconomic status stand a better chance of career advancement (Adler \& Izraeli, 1994). The point of socioeconomic is important especially in developing countries and may play an essential role in determining career success more than gender (Mansor, 1994). Moreover, the existing standards that are associated with work area for any individual like experience and knowledge, achieving higher level of assignments and perfect performance helps to have a good opportunity in determining a higher position in work (Adler, Brody, 2000). The most important factor that reflects a big impact on women's and plays an essential role in its career advancement is parental encouragement that generates success (Betz \& Fitzgerald, 1987).

Under this point, there are two issues to be discussed: job status (e.g., corporate culture and practices) and home (e.g., spousal support and family responsibilities). About the first issue, it's known that male's success is a barrier that face women's in their careers (Adler, 1993). Second issue indicates that female professionals suffer they are married and have children (Davidson \& Cooper, 1987; Ragins \& Sundstrom, 1989). According to these situations; with all the respect to family situation, it is clear that many men consider women's primary responsibility is taking care of her family (husband, children, parents), and if women make decision to develop herself and seek to own a good opportunity in her career advancement, she has to complete her responsibilities in home without detracting from any of its roles (Esmer, 1991). The previous discussed factors show that inequality between genders constitutes a potential barrier for female professional progress.

\section{Research Methodology}

This research examine academics' perception of women as managers and their career 
progression. The questionnaire of this research examines two main sections. The first section examines attitudes towards perception of gender roles. The second section scrutinizes opinions on female career progression. The research problem examines the stereotypes that faced women studying the problem of inequality between males and females in working zone, and the problem of not empowering women to access higher positions in career advancement. Many societies have these problems especially in patriarchal societies (Dalati 2021). The problem of this research examines the differences between men and women academics according to gender role stereotypes towards female career advancement. According to the findings of prior studies that were conducted in Middle East indicated inequality between men and women exist, which leads to lack of empowerment for women in management (Mostafa, 2005). This research perception of Syrian academics towards gender roles, investigating gender differences between among Syrian academics associated with gender roles. In addition, this research examines the perception of Syrian academics towards women career advancement, investigating gender differences among Syrian academics associated with women career advancement. Table 1 illustrate research hypotheses.

Table 1: Research hypotheses

\begin{tabular}{|c|c|c|}
\hline NO. & Statement & Test \\
\hline H1 & $\begin{array}{c}\text { Syrian academics have below average attitudes towards } \\
\text { women gender roles. }\end{array}$ & One sample t-test \\
\hline H2 & $\begin{array}{c}\text { There are gender differences among Syrian academics } \\
\text { associated with perception of women gender role. }\end{array}$ & Two sample t-test \\
\hline H3 & $\begin{array}{c}\text { Syrian academics have below average attitudes towards } \\
\text { women career advancement. }\end{array}$ & One sample t-test \\
\hline H4 & $\begin{array}{c}\text { There are gender differences among Syrian academics } \\
\text { associated with attitudes towards women career } \\
\text { advancement. }\end{array}$ & Two sample t-test \\
\hline
\end{tabular}

\subsection{Research variables measurement scales}

\subsubsection{Attitude towards perception of gender roles}

In this section, there are a list of statements regarding attitudes towards perception of gender roles in higher education sector. Attitude towards perception of gender roles is measured on 12 items subscale on a five-point Likert scale.

Table 2: Attitude towards perception of gender roles

1. Women academic are less capable of contributing to work academic than men.

2. Women care not able to be assertive in work circumstances that request it.

3. Women are not as much as men in learning digital and statistical knowledge.

4. Women are not as much as men in learning statistical and mathematical knowledge.

5. At home situation of workers there exist more trouble between husband and wife. 


\begin{tabular}{|l|}
\hline 6. Being a good mother and near her husband is the right situation for a woman \\
\hline $\begin{array}{l}\text { 7.Staying at home all the time with children is better for a woman than working outside } \\
\text { the home at least half time }\end{array}$ \\
\hline 8. Assuming academic leadership role as often as men is not acceptable for women \\
\hline 9. Family life of a working person is disorganized. \\
\hline 10. The reason of success of women managers can be the chance factor of work \\
\hline 11. The reason of success of women managers can be the chance factor of work \\
\hline 12. Having a challenging work is more important to men that it is for women \\
\hline
\end{tabular}

\subsubsection{Attitudes on female career advancement}

In this section, there are a list of statements regarding attitudes towards female professional improvement. Attitudes towards women's career advancement is measured on 5-item subscale on a five-point Likert scale.

Table 3: Attitudes towards female career advancement

\begin{tabular}{|l|}
\hline 1. Women competition with men is acceptable \\
\hline 2. The work of female managers should be appreciated as the work of male managers \\
\hline 3. Having women in key managerial positions should be accepted someday \\
\hline 4. The objectivity to evaluate business properly is possessed by women \\
\hline 5. The self-confidence required for a good leader is possessed by women \\
\hline
\end{tabular}

Methodology is the conceptual examination of strategies employed on research problem. This comprises research paradigm, theoretical model and quantitative or qualitative approaches (Al-Ajeeb, 2018). Research methodology determines a range of theoretical, process techniques that should be implemented during the research design. Good research is usually based on scientific reasoning and empirical testing. Empirical testing makes observations and defines variables methods and procedures and develop testable hypotheses (Cooper and Schindler, 2014). This research is based on deductive approach. Deduction is a form of examination where the researcher deducts a hypotheses that must then be exposed to observed testing (Bryman \& Bell, 2011).

Sampling design. There exist many causes, which would lead researchers to employ sampling approaches including the less cost, better accuracy, more rapidity of data collection, and accessibility of population elements (Cooper and Schindler, 2003). Data is collected during November and December 2020. The sample size includes 100 academics from a private university in Syria. The sampling strategy in this research is based on quota nonprobability sampling. Quota sampling is a type of purposive sampling; it is used to improve the representation of population. The main reason why researchers choose quota samples is that it allows researcher to sample subgroup that reflects an essential benefit to the study, so it is an ideal technique to investigate the traits of specific subgroups (Zikmund, 2013, Cooper and Schindler, 2003).

Questionnaire design. The questionnaire measurement design is based on two parts. The first part was concerned with personal characteristic's information of participants to the according questionnaire. The second part employed Turkish edition of WAMS (Women as Managers) Scale. This scale includes studying the 
problem of gender-role stereotypes. Second, it may be an old instrument but it still adopted for detecting the society attitudes towered women's career advancement (Aycan 2004). Academic respondents express their own opinion by choosing one of mentioned options according to the followed scale.

Applying Likert scale, participant is asked to code in their attitude towards requested statement. Respondents are asked to score a number to their attitude whether to agree or disagree. The measurement scale in this research study employs a five-point Likert scale.

Questionnaire translation. The tool has been translated to Arabic, due to better understanding and accuracy for respondents. This process reflects the consistency in understanding the questions that lead to reliable answers. The questionnaire is translated from English to Arabic. Consequently, the Arabic edition of the questionnaire was distributed to a group of academics in the field of business to inspect any points of development in the structure and wording of the questionnaire. Consequently, improvements were performed on the questionnaire wording after comments responded by the expert panel.

\section{Research results}

Demographic analysis. The demographic profile includes respondents' faculty, gender, age, management position, academic level, year of practice, and schooling. Descriptive data indicates that the targeted sample is from different faculties as follows $17.3 \%$ from BA, $24.5 \%$ from Pharmacy, $7.1 \%$ from IT, $6.1 \%$ from Civil 25 Engineering, 14.3from Architecture, 12.2from Fine Art, 4.1\% from Dentistry, $6.1 \%$ from University Requirements. The mean score foe age 46.69; work experience is 6 years. $50 \%$ are male, $50 \%$ female, $14 \%$ obtain undergraduate degree , $28 \%$ graduate degree , and $58 \% \mathrm{PhDs}$ their academic level is $31 \%$ are lecturer, $40 \%$ are instructor, $20 \%$ are assistant professor and $9 \%$ professor. Besides, their administration position is $17 \%$ are head of the department, $8 \%$ are Vice-deans, $5 \%$ are deans and $70 \%$ are without administration position. Tables $4,5,6,7,8$, and 9 illustrate demographic analysis.

Table 4: Sample distribution across faculty ( $n=100$, source: developed by authors)

\begin{tabular}{|c|c|c|}
\hline Faculty & Frequency & Percent $(\boldsymbol{\%})$ \\
\hline BA & 17 & 17.3 \\
\hline Pharmacy & 24 & 24.5 \\
\hline Civil Engineering & 6 & 6.1 \\
\hline Law & 8 & 8.2 \\
\hline Arts & 12 & 12.2 \\
\hline Architecture & 14 & 14.3 \\
\hline IT & 7 & 7.1 \\
\hline Dentistry & 4 & 4.1 \\
\hline University Requirements & 6 & 6.1 \\
\hline Total & 98 & 100.0 \\
\hline
\end{tabular}


Table 5: Sample demographic profile ( $\mathrm{n}=100$, source: developed by authors)

\begin{tabular}{|c|c|c|c|}
\hline Demographic profile & $\mathbf{N}$ & $\mathbf{M}$ & SD \\
\hline Age & 100 & 46.28 & 12.030 \\
\hline Work Experience & 100 & 6.20 & 4.43 \\
\hline
\end{tabular}

Table 6: Distribution of gender ( $n=100$, source: developed by authors)

\begin{tabular}{|c|c|c|}
\hline Gender & Frequency & Percent $(\boldsymbol{\%})$ \\
\hline Male & 50 & 50 \\
\hline Female & 50 & 50 \\
\hline Total & 100 & 100 \\
\hline
\end{tabular}

Table 7: Distribution of education level ( $\mathrm{n}=100$, source: developed by authors)

\begin{tabular}{|c|c|c|}
\hline Education level & Frequency & Percent $(\%)$ \\
\hline Bachelor & 14 & 14.0 \\
\hline Master & 28 & 28.0 \\
\hline PhD & 58 & 58.0 \\
\hline Total & 100 & 100 \\
\hline
\end{tabular}

Table 8: Academic level ( $\mathrm{n}=100$, source: developed by authors)

\begin{tabular}{|c|c|c|}
\hline Academic level & Frequency & Percent $(\boldsymbol{\%})$ \\
\hline Lecturer & 31 & 31.0 \\
\hline Instructor & 40 & 40.0 \\
\hline Associate professor & 20 & 20.0 \\
\hline Professor & 9 & 9.0 \\
\hline Total & 100 & 100.0 \\
\hline
\end{tabular}

Table 9: Administration position ( $\mathrm{n}=100$, source: developed by authors)

\begin{tabular}{|c|c|c|}
\hline Administration position & Frequency & Percent (\%) \\
\hline Head of department & 17 & 17.0 \\
\hline Vice dean & 8 & 8.0 \\
\hline Dean & 5 & 5.0 \\
\hline Academic staff & 70 & 70.0 \\
\hline Total & 100 & 100.0 \\
\hline
\end{tabular}

Reliability analysis. Reliability analysis is calculated to examine the consistency of items in the four sections to know if there is consistency between them or not. The acceptable levels of reliability are 0.70 and more, therefore there is consistency between items. If the value was smaller than 0.70 that means there is a weak reliability and less acceptable and therefore there is no consistency between items. In this research the alpha value of the two sections was higher than $70 \%$ so that means there is good consistency between items and the high degree of reliability, but the second two sections value was smaller than $70 \%$, for this reason reliability was not adopted. Table 10 illustrate reliability analysis. 
Table 10: Reliability analysis, Cronbach alpha $(\mathrm{n}=100)$

\begin{tabular}{|c|c|c|}
\hline Variable Component & Items & Alpha ( $\boldsymbol{\alpha})$ value \\
\hline Attitude towards perception of gender roles. & 12 & 0.82 \\
\hline Attitudes towards women's career advancement. & 5 & 0.89 \\
\hline
\end{tabular}

Descriptive analysis. Descriptive statistics illustrates two sections namely attitudes towards perception of gender roles, and attitudes towards female professional progression. Tables 11 , and 12 indicate means scores and standard deviation for the above-mentioned sections.

Table 11 illustrates mean scores and standard deviation for attitudes towards perception of gender roles. Statements 3 and 8 have the highest score. Respondents disagreed that women are less capable than men in learning digital and technical skills are. This means they do not have negative attitudes towards women's ability for learning digital skills. However, in contrast participants agreed that the suitability factor of work to women could be the reason for the success women of managers. This is the lowest score in this section. Overall, in this section respondents do not indicate negative attitudes towards women academics.

Table 11: Descriptive analysis of attitude towards perception of gender roles $(n=100)$

\begin{tabular}{|c|c|c|}
\hline Attitude Towards Perception of Gender & $\mathbf{M}$ & SD \\
\hline $\begin{array}{l}\text { Women academic are less capable of contributing to work } \\
\text { academic than men. }\end{array}$ & 4.2900 & .96708 \\
\hline $\begin{array}{l}\text { 1. Women care not able to be assertive in work } \\
\text { circumstances that request it. }\end{array}$ & 3.8700 & 1.10696 \\
\hline $\begin{array}{l}\text { 2. Women are not as much as men in learning digital and } \\
\text { statistical knowledge. }\end{array}$ & 4.3600 & .91585 \\
\hline $\begin{array}{l}\text { 3. Women are not as much as men in learning statistical and } \\
\text { mathematical knowledge. }\end{array}$ & 4.2100 & .95658 \\
\hline $\begin{array}{l}\text { 4. At home situation of workers there exist more trouble } \\
\text { between husband and wife. }\end{array}$ & 3.0800 & 1.02178 \\
\hline $\begin{array}{l}\text { 5. Being a good mother and near her husband is the right } \\
\text { situation for a woman }\end{array}$ & 3.8600 & 1.11934 \\
\hline $\begin{array}{l}\text { 6. Staying at home all the time with children is better for a } \\
\text { woman than working outside the home at least half time }\end{array}$ & 3.8600 & 1.18935 \\
\hline $\begin{array}{l}\text { 7. Assuming academic leadership role as often as men is not } \\
\text { acceptable for women }\end{array}$ & 4.3600 & .87062 \\
\hline 8. Family life of a working person is disorganized. & 3.7300 & 1.10878 \\
\hline $\begin{array}{l}\text { 9. The reason of success of women managers can be the } \\
\text { chance factor of work }\end{array}$ & 3.8600 & 1.13725 \\
\hline $\begin{array}{l}\text { 10. The reason of success of women managers can be the } \\
\text { chance factor of work }\end{array}$ & 2.4400 & 1.21705 \\
\hline $\begin{array}{l}\text { 11. Having a challenging work is more important to men that } \\
\text { it is for women }\end{array}$ & 3.8200 & 1.07666 \\
\hline
\end{tabular}

Table 12: Descriptive analysis of attitudes towards women's career advancement $(n=100)$ 


\begin{tabular}{|l|c|c|}
\hline Women competition with men is acceptable & 3.99 & .893 \\
\hline $\begin{array}{l}\text { The work of female managers should be appreciated as the work of } \\
\text { male managers }\end{array}$ & 4.39 & .777 \\
\hline $\begin{array}{l}\text { Having women in key managerial positions should be accepted } \\
\text { someday }\end{array}$ & 4.22 & .905 \\
\hline The objectivity to evaluate business properly is possessed by women & 3.79 & 1.057 \\
\hline The self-confidence required for a good leader is possessed by women & 4.07 & .891 \\
\hline
\end{tabular}

Table 12 illustrates mean scores and standard deviation for attitudes towards women career advancement. Statement 2 have the highest score. Respondents agreed that society should regard work by female managers as valuable as work by male managers. This means that respondents don't have a negative attitude toward female managers work. In statement 4 there is the lowest score. Even though it still has a positive attitude towards women, because it closer to agreement that women have the objectively required to evaluate business situations properly. Overall, in this section respondents do not indicate negative attitudes towards women academics. Table 13 illustrates mean scores and standard deviation for research variables grand means. Attitudes towards women's career advancement have the highest score.

Table 13: Descriptive analysis of research variables grand means $(n=100)$

\begin{tabular}{|c|c|c|}
\hline Research Variables Grand Means & M & SD \\
\hline Attitude towards perception of gender roles & 3.81 & .616 \\
\hline Attitudes towards women's career advancement & 4.09 & .761 \\
\hline
\end{tabular}

Descriptive analysis across gender. Tables 14 and 15 illustrates gender differences between male and female respondents. Overall, male respondents have different scores than female respondents, where the later indicate higher scores than male participants. This means female respondents have higher favorable attitudes towards women playing equal roles to men.

Table 14: Attitudes towards perception of gender roles - comparison across gender

$$
(n=100)
$$

\begin{tabular}{|l|c|c|c|c|}
\hline \multicolumn{1}{|c|}{ Attitude towards perception of gender roles } & \multicolumn{2}{|c|}{ Male } & \multicolumn{2}{c|}{ Female } \\
\cline { 2 - 5 } & $\mathbf{M}$ & SD & M & SD \\
\hline $\begin{array}{l}\text { Women academic are less capable of contributing to work } \\
\text { academic than men. }\end{array}$ & 3.92 & 1.103 & 4.66 & .626 \\
\hline $\begin{array}{l}\text { Women care not able to be assertive in work } \\
\text { circumstances that request it. }\end{array}$ & 3.64 & 1.083 & 4.10 & 1.09 \\
\hline $\begin{array}{l}\text { Women are not as much as men in learning digital and } \\
\text { statistical knowledge. }\end{array}$ & 4.18 & 1.063 & 4.54 & .705 \\
\hline $\begin{array}{l}\text { Women are not as much as men in learning statistical and } \\
\text { mathematical knowledge. }\end{array}$ & 4.08 & 1.026 & 4.34 & .871 \\
\hline $\begin{array}{l}\text { At home situation of workers there exist more trouble } \\
\text { between husband and wife. }\end{array}$ & 2.98 & .9998 & 3.18 & 1.04 \\
\hline
\end{tabular}




\begin{tabular}{|l|c|c|c|c|}
\hline $\begin{array}{l}\text { Being a good mother and near her husband is the right } \\
\text { situation for a woman }\end{array}$ & 3.46 & 1.198 & 4.26 & .876 \\
\hline $\begin{array}{l}\text { Staying at home all the time with children is better for a } \\
\text { woman than working outside the home at least half time }\end{array}$ & 3.50 & 1.182 & 4.22 & 1.09 \\
\hline $\begin{array}{l}\text { Assuming academic leadership role as often as men is not } \\
\text { acceptable for women }\end{array}$ & 4.10 & 1.015 & 4.62 & .602 \\
\hline Family life of a working person is disorganized. & 3.44 & 1.109 & 4.02 & 1.03 \\
\hline $\begin{array}{l}\text { The reason of success of women managers can be the } \\
\text { chance factor of work }\end{array}$ & 3.68 & 1.019 & 4.04 & 1.22 \\
\hline $\begin{array}{l}\text { The reason of success of women managers can be the } \\
\text { chance factor of work }\end{array}$ & 2.36 & 1.083 & 2.52 & 1.34 \\
\hline $\begin{array}{l}\text { Having a challenging work is more important to men that } \\
\text { it is for women }\end{array}$ & 3.68 & 1.038 & 3.96 & 1.10 \\
\hline
\end{tabular}

Table 15: Attitudes towards women's career advancement - comparison across gender

\begin{tabular}{|l|c|c|c|c|c|}
\hline \multirow{2}{*}{ Attitudes towards women's career advancement } & \multicolumn{2}{|c|}{ Male } & \multicolumn{3}{c|}{ Female } \\
\cline { 2 - 6 } & $\mathbf{M}$ & SD & M & SD \\
\hline Women competition with men is acceptable & 3.92 & .922 & 4.06 & .867 \\
\hline $\begin{array}{l}\text { The work of female managers should be appreciated as the } \\
\text { work of male managers }\end{array}$ & 4.22 & .790 & 4.56 & .733 \\
\hline $\begin{array}{l}\text { Having women in key managerial positions should be } \\
\text { accepted someday }\end{array}$ & 4.02 & .915 & 4.42 & .859 \\
\hline $\begin{array}{l}\text { The objectivity to evaluate business properly is possessed } \\
\text { by women }\end{array}$ & 3.50 & 1.147 & 4.08 & .877 \\
\hline $\begin{array}{l}\text { The self-confidence required for a good leader is possessed } \\
\text { by women }\end{array}$ & 3.82 & .850 & 4.32 & .868 \\
\hline
\end{tabular}

Table 16: Gender descriptive analysis of research variables grand means $(n=100)$

\begin{tabular}{|l|c|c|c|c|}
\hline \multirow{2}{*}{ Research Variables Grand Means } & \multicolumn{2}{|c|}{ Male } & \multicolumn{2}{c|}{ Female } \\
\cline { 3 - 5 } & M & SD & M & SD \\
\hline 1. Attitude towards perception of gender roles & 3.58 & .659 & 4.03 & .477 \\
\hline $\begin{array}{l}\text { 2. } \\
\text { Attitudes towards women's career } \\
\text { advancement }\end{array}$ & 3.89 & .788 & 4.28 & .687 \\
\hline
\end{tabular}

Table 16 illustrates gender differences between male and female respondents. Opinions towards women's career advancement for both male and female have the highest score, male participants have agreed the statement, in contrast female participants have strongly agreed the statement.

Research findings and propositions. The first proposition in this research examines academics attitudes towards gender roles. To test the first hypothesis, we conducted one sample t-test. The result for attitudes towards perception of gender role confirms that sample mean is significantly different from population mean were $\mathrm{t}(99)=13,162, \mathrm{P}=0.000$. This confirms that academics perception of gender role is 
not negative. Academics do not have negative perception of academic women work and capability to perform well as men academic.

To test the second hypothesis, we performed two-sample t-test on attitudes towards perception of gender role to compare male and female attitudes. Two sample t-test confirms that male academics attitudes is significantly different from female attitudes were $\mathrm{t}(98)=-3.935, \mathrm{P}=0.000$. This confirms that female attitudes have more favorable attitudes towards female gender role. To test the third hypothesis, we conducted one sample t-test. The result of one sample t-test for attitudes towards women career advancement confirms that the sample mean is significantly different from population mean were $\mathrm{t}(99)=14.332, \mathrm{P}=0$. 000 . This confirms that academics do not have negative attitudes towards women career advancement. Academics believe that it is acceptable for women to compete with men for top executive position.

To test the fourth hypothesis, we performed two-sample t-test on attitudes toward women career advancement to compare male and female attitudes. Two sample t-test confirms that male academics attitudes is significantly different from female attitudes were $\mathrm{t}(98)=-2.720, \mathrm{P}=0.008$. This confirms that female participant holds higher favorable attitudes towards women career advancement than men participant does.

Tables 17, 18, 19 and 20 illustrates descriptive analysis of one sample and twosample t-test for research variables.

Table 17: One sample descriptive statistics

\begin{tabular}{|l|c|c|c|}
\hline \multicolumn{1}{|c|}{ One Sample T Test } & M & SD & SE Mean \\
\hline Attitude towards perception of gender roles & 3.8117 & .61667 & .06167 \\
\hline Attitudes towards women's career advancement & 4.0920 & .76193 & .07619 \\
\hline
\end{tabular}

Table 18: One sample t-test

\begin{tabular}{|l|c|c|c|c|c|c|}
\hline \multirow{2}{*}{ One sample t-test } & \multicolumn{5}{|c|}{ Test Value = 3 } \\
\cline { 2 - 7 } & $\mathbf{t}$ & $\mathbf{d f}$ & $\begin{array}{c}\text { Sig. } \\
\mathbf{2}- \\
\text { tailed) }\end{array}$ & $\begin{array}{c}\text { Mean } \\
\text { Difference }\end{array}$ & $\begin{array}{c}\text { 95\% Confidence } \\
\text { Interval of the } \\
\text { Difference }\end{array}$ \\
\cline { 4 - 7 } & 13.162 & 99 & .000 & .81167 & .6893 & .9340 \\
\hline $\begin{array}{l}\text { Attitude towards } \\
\text { perception of } \\
\text { gender roles }\end{array}$ & 14.332 & 99 & .000 & 1.09200 & .9408 & 1.2432 \\
\hline $\begin{array}{l}\text { Attitudes towards } \\
\text { women's career } \\
\text { advancement }\end{array}$ & & & & & & \\
\hline
\end{tabular}

Table 19: Two samples descriptive statistics

\begin{tabular}{|c|c|c|c|c|c|}
\hline $\begin{array}{l}\text { Two Samples } \\
\text { descriptive statistics }\end{array}$ & Gender & $\mathbf{N}$ & Mean & $\begin{array}{c}\text { Std. } \\
\text { Deviation }\end{array}$ & $\begin{array}{l}\text { Std. Error } \\
\text { Mean }\end{array}$ \\
\hline \multirow{2}{*}{$\begin{array}{l}\text { Attitude towards } \\
\text { perception of gender } \\
\text { roles }\end{array}$} & Male & 50 & 3.5850 & .65993 & .09333 \\
\hline & Female & 50 & 4.0383 & .47744 & .06752 \\
\hline \multirow{2}{*}{$\begin{array}{l}\text { Attitudes towards } \\
\text { women's career } \\
\text { advancement }\end{array}$} & Male & 50 & 3.8960 & .78894 & .11157 \\
\hline & Female & 50 & 4.2880 & 68709 & .09717 \\
\hline
\end{tabular}




\section{Discussions, limitation and future research}

According to the test that we conducted in this research, we found that the obtained results are similar to the previous result (aycan 2004). In spite of the fact of research, results are generally in favor of women academics work and management. However, there is still significant difference between men and women responses and attitudes. This means initiatives can be taken to promote women as managers. For example, universities may conduct awareness workshops to promote for female academic management. Training workshops can also be designed to enhance women managerial skills and capabilities.

The first research limitations are associated with sample size and limited scope. The study focused only on one institution. Therefore, it is not possible to generalize research results. The second limitation is associated with research method, which is survey questionnaire; the data was collected through self-administrative distributed to respondents. There is a possibility that the respondents may not have indicated authentic responses. For example, in more than one case respondents indicated inconsistency between what they selected in the questionnaire and what they discussed with us.

Table 20: Two samples t-test

\begin{tabular}{|c|c|c|c|c|c|c|}
\hline \multirow{2}{*}{\multicolumn{3}{|c|}{ Two Samples T-Test }} & \multicolumn{2}{|c|}{$\begin{array}{c}\text { Attitude towards } \\
\text { perception } \\
\text { of gender roles }\end{array}$} & \multicolumn{2}{|c|}{$\begin{array}{l}\text { Attitudes towards women's } \\
\text { career advancement }\end{array}$} \\
\hline & & & \multirow{2}{*}{$\begin{array}{c}\begin{array}{l}\text { Equal } \\
\text { variances } \\
\text { assumed }\end{array} \\
3.081\end{array}$} & \multirow{2}{*}{$\begin{array}{l}\text { Equal } \\
\text { variances } \\
\text { assumed } \\
\end{array}$} & \multirow{2}{*}{$\begin{array}{c}\begin{array}{l}\text { Equal } \\
\text { variances } \\
\text { not assumed }\end{array} \\
0.288\end{array}$} & \multirow{2}{*}{$\begin{array}{l}\text { Equal } \\
\text { variances } \\
\text { not assumed }\end{array}$} \\
\hline $\begin{array}{l}\text { Levene's } \\
\text { Test for }\end{array}$ & \multicolumn{2}{|l|}{$\mathrm{F}$} & & & & \\
\hline $\begin{array}{c}\text { of } \\
\text { Variances }\end{array}$ & \multicolumn{2}{|c|}{ Sig. } & 0.082 & & 0.592 & \\
\hline \multirow{7}{*}{$\begin{array}{l}\text { t-test for } \\
\text { Equality } \\
\text { of Means }\end{array}$} & \multicolumn{2}{|l|}{$\mathrm{t}$} & -3.935 & -3.94 & -2.649 & -2.649 \\
\hline & \multicolumn{2}{|c|}{ df } & 98 & 89.26 & 98 & 96.185 \\
\hline & \multicolumn{2}{|c|}{ Sig. (2-tailed) } & 0 & 0 & 0.009 & 0.009 \\
\hline & \multicolumn{2}{|c|}{ Mean Difference } & -0.45333 & -0.45 & -0.392 & -0.392 \\
\hline & \multicolumn{2}{|c|}{$\begin{array}{c}\text { Std. Error } \\
\text { Difference } \\
\end{array}$} & 0.11519 & 0.115 & 0.14795 & 0.14795 \\
\hline & \multirow{2}{*}{$\begin{array}{c}95 \% \\
\text { Confidence } \\
\text { Interval of } \\
\text { the } \\
\text { Difference }\end{array}$} & Lower & -0.68193 & -0.68 & -0.68561 & -0.68568 \\
\hline & & Upper & -0.22474 & -0.22 & -0.09839 & -0.09832 \\
\hline
\end{tabular}

Table 21: Hypothesis testing result

\begin{tabular}{|c|l|c|c|}
\hline No. & \multicolumn{1}{|c|}{ Statement } & Findings & Results \\
\hline H1 & $\begin{array}{l}\text { Syrian academics have below } \\
\text { average attitudes towards women } \\
\text { gender roles. }\end{array}$ & $\begin{array}{c}\mathrm{t}(99)=13,162, \\
\mathrm{P}=0.000\end{array}$ & $\begin{array}{c}\text { Hypothesis } \\
\text { rejected }\end{array}$ \\
\hline
\end{tabular}




\begin{tabular}{|c|l|c|c|}
\hline $\mathbf{H 2}$ & $\begin{array}{l}\text { There are gender differences among } \\
\text { Syrian academics associated with } \\
\text { perception of women gender role. }\end{array}$ & $\begin{array}{c}\mathrm{t}(98)=-3.935, \\
\mathrm{P}=0.000 .\end{array}$ & $\begin{array}{c}\text { Hypothesis } \\
\text { accepted }\end{array}$ \\
\hline $\mathbf{H 3}$ & $\begin{array}{l}\text { Syrian academics have below } \\
\text { average attitudes towards women } \\
\text { career advancement. }\end{array}$ & $\begin{array}{c}\mathrm{t}(99)=14.332, \\
\mathrm{P}=0.000 .\end{array}$ & $\begin{array}{c}\text { Hypothesis } \\
\text { rejected }\end{array}$ \\
\hline $\mathbf{H 4}$ & $\begin{array}{l}\text { There are gender differences among } \\
\text { Syrian academics associated with } \\
\text { attitudes towards women career } \\
\text { advancement. }\end{array}$ & $\begin{array}{c}\mathrm{t}(98)=-2.720, \\
\mathrm{P}=0.008 .\end{array}$ & $\begin{array}{c}\text { Hypothesis } \\
\text { accepted }\end{array}$ \\
\hline
\end{tabular}

The recommendation for future research is to examine larger samples for different geographical locations not only Damascus. In addition, future research should examine both private and public universities. In addition, future research should consider different research methodologies. For example: focus groups and interviews could enable the researcher to obtain deeper understanding of research problem.

This research examined four variables, which are attitudes towards gender roles, attitudes towards women's career advancement, attitudes towards women's femininity in business life and attitudes towards women managers. The obtained results of male and female respondents were positive and negative responses. It is noted that elder male participants have a positive attitude towards academic women, and support women more than youngest male participants. Responses were favorable because, the survey was tested on elite academics from Arab International University.

\section{References}

Adler, N. J. (1993). An International Perspective on the Barriers to the Advancement of Women Managers, Applied Psychology, 42(4), 289-300.

Adler, N.J., \& Izraeli, D.N. (Eds.) (1994). Competitive frontiers: Women managers in a global economy. Malden, MA: Blackwell.

Adler, N.J. (1994). Asian women in management. International Studies of Management and Organization, 23(4), 23-38.

Adler, N.J., Brody, L.W., \& Osland, J.S. (2000). The women's global leadership forum: Enhancing one company's global leadership capability. Human Resource Management, 39(3), 209-225.

Almenkash, S., Abdulaziz, M., Shaman, A., Haijan, A. and Dagsh, N. (2007), The Issue of Management Women/Men in Higher Education Institutions for Girls, The Draft Plan for the Future of Higher Education in the Kingdom of Saudi, King 
Abdullah Institute for Research Consultancy Studies, Al-Riyadh.

Asya Al-Lamky, (2007). Feminizing leadership in Arab societies: the perspectives of Omani female leaders, Women in Management Review, 22(1), 49 - 67.

Athmar Al-Salem Mark Speece, (2017), Women in leadership in Kuwait: a research agenda, Gender in Management: An International Journal, 32(2).

Aycan, Z. (2004). Key success factors for women in management in Turkey, Applied Psychology.

Al-Salem, A. (2007-2013). Multiple unpublished small surveys conducted as part of management classes at American University of Kuwait.

Al-Ajeeb, L. (2018) Scientific Research Methodology Steps.

Betz, N., \& Fitzgerald, L. (1987). The career psychology of women. New York: Wiley.

Bryman, A. and Bell, E. (2011). Bussines Research Method. $3^{\text {rd }}$ Ed. Oxford ( Oxford University Press).

Cooper, D.R., \& Schindler, P.S. (2014). Business research methods (12th ed.). New York: McGraw Hill.

Cooper, D.R. and Schindler, P.S. (2003) Business Research Methods. 8th Edition, McGraw-Hill Irwin, Boston.

Dalati, S. (2021). Factors affecting Syrian female researchers' experience during crisis: inductive approach. Business, Management and Economics Engineering, 19(1), 91-110.

Dalati, S., Eddin, S., \& Hamwi, A. (2016). Sustainable development in higher education through service quality and price fairness: empirical evidence from private universities in Damascus, Syria. The International Journal Entrepreneurship and 
Sustainability Issues, 4(1).

Dalati, S., Raudeliuniene, J., Davidaviciene, V. (2020). Innovations in the management of higher education: situation analysis of Syrian female students empowerment, Marketing and Management of Innovations, 4, 245-254.

Davidson, M.J., \& Cooper, C.L. (1987). Managers in Britain-A comparative perspective. Human Resource Management, 26, 217-242.

Esmer, Y. (1991). Values in Turkish society. Istanbul: TUSIAD.

Elizabeth McDermott, (1998). Barriers to women's career progression in LIS, Library Management, 19(7), 416-420.

Hodges, J. (2017). Cracking the walls of leadership: women in Saudi Arabia, Gender in Management: An International Journal, 32(1), 34-46.

Greenhaus, P.H., \& Parasuraman, S. (1993). Job performance attributions and career advancement prospects: An examination of gender and race effects. Organizational Behavior and Human Decision Processes, 55, 273-297.

Lobel, S.A., \& St Clair, L. (1992). Effects of family responsibilities, gender, and career identity salience on performance outcomes. Academy of Management Journal, 35(5), 1057-1069.

Ne Norma Mansor. (1994). Women Managers in Malaysia: Their Mobility and Challenges in Competitive Frontiers, in Nancy J. Adler and Dafna N. Izraeli (eds.), Women Managers in Global Economy, Blackwell Publishers, Oxford, chap. 6, 101113. New York: Cengage Learning.

Ragins, B.R., \& Sundstrom, E. (1989). Gender and power in organizations. Psychological Bulletin, 105, 51-88.

Shahine, Z. (1997), "Women and management", Paper submitted in the First Annual 
Conference of Arab Women Leaders and Sustainable Development, Alexandria.

Tharenou, P. and Conroy, D. (1994). Men and women managers advancement personal or situational determinants, Appl. Psychol.-Int. Rev.-Psychol. Appl.-Rev. Int.

Zikmund, G., Carr, J. C., Griffin, M., \& Babin, B. J. (2013). Business Research Methods (9th ed.). 